$\begin{array}{lll}\text { KULTURA } & \begin{array}{l}\text { POLSKA A KADEMIA NAUK } \\ \text { KOMITET SOCJOLOGII }\end{array} & \text { ISSN 0023-5172 } \\ \text { i } & \begin{array}{l}\text { INSTYTUT ST DIÓW POLITYCZNYCH } \\ \text { SPOLECLENSTMO nr 4 }\end{array} & \text { WYMIARY POLITYCZNOŚCI }\end{array}$

RENATA DOPIERAŁA

Uniwersytet Łódzki

\title{
MINIMALIZM — MIĘDZY EPIZODEM A TRWANIEM
}

Zamierzam przedstawić opis i interpretację minimalizmu jako przykładu zjawiska, które - na bazie krytyki konsumpcjonizmu - jest propozycją przekierowania dążeń jednostki w stronę dóbr niematerialnych, a zarazem zawiera ofertę metod użytecznych w toku przeprowadzenia takiej reorganizacji własnego życia. Aby zrealizować wskazany cel:

— omówię założenia minimalizmu, zestawiając go ze slow life oraz, wcześniejszą chronologicznie, ideą dobrowolnej prostoty (voluntary simplicity);

- przedstawię przeobrażenia, jakim podlega minimalizm, a także warianty, $\mathrm{w}$ jakich może się manifestować;

— przedyskutuję zasadność postrzegania minimalizmu jako narzędzia projektowania siebie i konstruowania określonego stylu życia.

Zamierzenia te pozwolą zobrazować ciągłości i zerwania w obrębie wymienionych systemów idei oraz uwarunkowania wpływające na zmienność ich manifestacji. Bazę empiryczną rozważań stanowią teksty wytwarzane przez uczestników świata społecznego minimalistów, głównie pisane przez nich książki, najczęściej będące transformacją wcześniej istniejących blogów ${ }^{1}$.

Adres do korespondencji: renata_dopierala@poczta.onet.pl

${ }^{1}$ Blogi były istotne dla rozwoju i spopularyzowania minimalizmu (zob. Kasperek 2014b, 2013, Dopierała 2015). Fakt, że przekazy te początkowo funkcjonowały w internecie odpowiadał — zdaniem Andrzeja Kasperka — za popkulturową, strywializowaną wersję tej idei. Dyskusyjne jest, czy prezentowanie minimalistycznych przekonań w formie książek - coraz częściej poradników czyni je bardziej poważnymi. 


\section{DOBROWOLNA PROSTOTA I PROSTE ŻYCIE}

Termin voluntary simplicity (dobrowolna prostota, dobrowolne upraszczanie życia, proste życie) po raz pierwszy został użyty przez amerykańskiego filozofa Richarda Gregga w 1936 roku w tekście The Value of Voluntary Simplicity (1977 [1936]). Gregg, uczeń Mahatmy Gandhiego, definiował dobrowolną prostotę jako „życiodajną siłę” niezbędną do osiągania jednostkowych celów, pozwalającą przezwyciężyć złożoność i szybkość współczesnego świata. Jej sednem jest życie zgodne $z$ założonymi celami, harmonijna ich realizacja bazująca na uznaniu, że umiar i powściągliwość w pewnych dziedzinach (np. stan posiadania) skutkuje osiągnięciem większej „obfitości” w innych sferach życia (np. życie rodzinne, realizacja pasji). W upraszczaniu życia równie istotne jak działania w świecie zewnętrznym jest koncentrowanie się na przeżyciach i doświadczeniach wewnętrznych. Jak pisał w swoim eseju Gregg (1977, s. 20): „Voluntary Simplicity nie jest statyczna, jest procesem integrowania i równoważenia zewnętrznych i wewnętrznych aspektów naszego życia. Istotą prostego życia nie jest dogmatyczne «mniej» [live with less], ale raczej równowaga [live with balance], która prowadzi do bardziej spełnionego i satysfakcjonującego życia”. Tak pojmowana prostota nie jest - według niego — czymś archaicznym, lecz stanowi niezbędny środek służący do „naprawy” stechnicyzowanego świata - procesy industrializacji bowiem inicjują i intensyfikują dążenia do tego, co duchowe (por. Weber 2002; Ritzer 2001).

Uzasadnieniem posiadania rzeczy jest (czy powinien być) ich związek z wybranymi celami, gdyż są one niekiedy niezbędne do ich osiągnięcia - przejawia się w ten sposób ich utylitarna funkcja (Gregg 1977, s. 4). Rzeczy zbędne natomiast to takie, które nie wiążą się z owymi celami, nie są więc znaczące $z$ perspektywy jednostkowych zamierzeń (jest to wątek ważny zwłaszcza dla współczesnego minimalizmu), co więcej — ich nadmiar może przeszkadzać w dążeniu do celów istotnych życiowo, czyli innych niż materialnie pojmowane i dominujące społecznie. Każda jednostka projektuje odmienne cele, a to, co jest istotne dla jednej osoby, może różnić się od tego, jakich wyborów dokonuje ktoś inny. Dlatego też zakres wprowadzenia przynoszących satysfakcję uproszczeń (będących konsekwencją koncentracji na owych zamierzeniach) jest zróżnicowany. Nie ma jednej instrukcji „upraszczania życia” właściwej dla wszystkich — jej stosowanie w praktyce jest uzależnione od różnic indywidualnych, uznawanych wzorów kulturowych itp. (Gregg 1977; Elgin 1977).

W przywołanym fragmencie tekstu Gregga pojawiają się stwierdzenia istotne dla dalszego opisu i analizy — przede wszystkim opozycja wnętrze/zewnętrze. Dla idei prostego życia konstytutywne jest założenie o niemożności osiągnięcia „prawdziwego” zadowolenia i szczęścia, jeśli tkwi się w „okowach” uwarunkowań wytwarzanych przez współczesne społeczeństwa. Życie przemyślane, intencjonalnie kierowane, to znaczy zgodne $z$ wyznaczonymi celami, nie jest możliwe, gdy jest się rozproszonym, nieskoncentrowanym na obec- 
nej chwili, nieuważnym²; te właściwości określają egzystencję jednostki w złożonych zbiorowościach. Proponowany przez Gregga zwrot w stronę prostoty, a tym samym duchowości, oznacza między innymi traktowanie każdego momentu egzystencji jako godnego uwagi i szacunku, świadome zwracanie uwagi na „detale” życia.

Upowszechnienie idei dobrowolnej prostoty dokonało się - nieprzypadkowo - w latach siedemdziesiątych XX wieku za sprawą Duane Elgina i Arnolda Mitchella. Popularne było wówczas promowanie stylu życia polegającego na świadomej rezygnacji z nadmiernego konsumowania dóbr, co wiązało się z poglądami głoszonymi przez ruchy kontrkulturowe (Kasperek 2014a). Ci propagatorzy ruchu dobrowolnej prostoty (Voluntary Simplicity Movement) ujmowali życie proste jako „skromne materialnie, bogate emocjonalnie, intelektualnie i duchowo" (Elgin 2010, s. 90), co zawiera się w syntetycznej definicji współbrzmiącej z propozycją Gregga: „jej [dobrowolnej prostoty] istotą jest życie w sposób zewnętrznie prosty i wewnętrznie bogaty" (Elgin 2010, s. 93). Zaznacza się w niej opozycyjne nastawienie wobec postawy, którą można ująć jako „zewnętrzne bogactwo” i „wewnętrzna prostota”. Rozwijając tę myśl Elgin i Mitchell (1977, s. 4-11) wskazali pięć wartości opisujących egzystencję $\mathrm{w}$ prostocie. Są to: orientacja na człowieka (rozumiana także jako poszukiwanie ludzkiej miary); samookreślenie; rozwój osobowy (blisko związany z poprzednim elementem); świadomość ekologiczna oraz prostota materialna (czynnik istotny w kontekście minimalizmu).

Według Samuela Alexandra voluntary simplicity to „opozycyjna strategia odrzucająca zaawansowaną konsumpcję (ogólnie kulturę konsumpcyjną), materialistyczny styl życia i afirmująca to, co jest nazywane prostym życiem (simple living) lub "redukcją biegu» (downshifting)" (Alexander 2011, s. 6). Określana czasem jako „cicha rewolucja”, oznacza proste i bezpośrednie spełnianie potrzeb materialnych, minimalizowanie wydatków na dobra konsumpcyjne i usługi oraz przekierowanie czasu i wysiłków na niematerialne źródła satysfakcji indywidualnej i społecznej. David Shi (1985) zwraca uwagę na takie atrybuty prostego życia jak: zamierzona oszczędność; niechęć do luksusowych przedmiotów; szacunek dla natury; dążenie do samowystarczalności; przypisywanie większej ważności inwencji twórczej i kontemplacji niż posiadaniu; preferowanie minimalizmu i funkcjonalności; poczucie odpowiedzialności.

2 Określenia te zawierają się w — równie dziś popularnym - terminie „uważność” (mindfulness). Postrzega się ją jako jeden z wyróżników dobrowolnej prostoty i minimalizmu. Uważność jest „stanem świadomości polegającym na niespiesznej, neutralnej uwadze skupionej na jednej rzeczy w pewnym czasie" (Burch 2012, s. 34; por. Kasperek 2015, s. 51). Jej rozwijanie pozwala dotrzeć do duchowych intuicji, utrzymać kontakt $z$ wewnętrznym doświadczeniem. Dlatego uważność stanowi alternatywę dla społeczeństwa nadmiaru i pośpiechu. Obecnie wykracza poza kontekst religijno-duchowy, przejawia się w różnych aspektach codzienności, jest także „strategią” wykorzystywaną w radzeniu sobie ze stresem, w zarządzaniu itp. 
Czym zaś dobrowolna prostota nie jest, jakie wyobrażenia na jej temat są mylące? Większość takich przekonań jest rozpowszechniana przez teksty kultury popularnej, które ją banalizują, zniekształcają, paradoksalnie upraszczają, jednak nie w sensie preferowanym w kontekście prostego życia. Negacje dotyczą wielu kwestii różnej wagi. Zajmujący się tą problematyką autorzy podkreślają, że dobrowolnej prostoty nie należy utożsamiać z życiem $\mathrm{w}$ biedzie (por. Elgin 2010; Alexander 2011), to bowiem jest stanem narzuconym, odczuwanym jako deprywacja, marginalizacja i wykluczenie. Zdaniem Elgina nie powinno się jej postrzegać jako rodzaju poświęcenia lub wyrzeczenia, jej cechą nadrzędną jest bowiem dobrowolność i intencjonalny wybór, który ma prowadzić do poczucia zadowolenia i wdzięczności za to, co się posiada. Podkreśla się dążenie do wykształcenia takiego stanu mentalnego, który pozwala na odczuwanie szczęścia - nie w wymiarze materialnym, ale psychicznym. Praktykowanie dobrowolnej prostoty nie może być również kojarzone $z$ ascezą, bezkrytycznym odrzuceniem korzyści płynących z rozwoju nauki i techniki, koniecznością porzucenia dotychczasowego życia i stania się mnichem lub eremitą. Nie oznacza też regresu do (mniej lub bardziej wyobrażonego) stanu pierwotnego ludzkości, co więcej, nie jest jednoznaczne $z$ eskapizmem kojarzonym z hippisami, ekscentrykami, outsiderami (choć taka identyfikacja może się pojawić). Raczej sugeruje (to ważny tryb opisujący to zjawisko) zastanowienie się nad podejściem do pieniędzy i materialnego posiadania, nad kondycją planety, relacjami $z$ innymi oraz nad samymi sobą (Alexander 2011; Elgin 2010).

Topos poszukiwań sensu życia w sposób odmienny od powszechnie podzielanych wyobrażeń nie jest oczywiście nowy, nie pojawił się ani na początku $\mathrm{XX}$ wieku, ani w jego ostatnich dekadach. Jego antecedencje - w różnym zakresie i stopniu zapożyczone oraz przetworzone - można odnaleźć w filozofii starożytnej (w stoicyzmie, epikureizmie), religiach Wschodu (buddyzmie, taoizmie) oraz poglądach transcendentalistów amerykańskich (Ralpha Waldo Emersona i Henry'ego Davida Thoreau). Kolejnym przejawem tej - określonej przez Andrzeja Kasperka (2014a) — „tendencji kulturowej”, którą cechuje chęć powrotu do natury, proste życie, uwolnienie od materialnych obciążeń, były ruchy kontrkulturowe. Uprawnia to do sformułowania tezy, że idea voluntary simplicity (simple living) „istniała zawsze”, przyjmowała jedynie różne manifestacje, zmieniając się wraz z kontekstami kulturowymi i społecznymi.

Występujący w tekstach Gregga i Elgina podział na „sferę materii” i „sferę ducha" współbrzmi z przekonaniami głoszonymi w szkole frankfurckiej, zwłaszcza przez Herberta Marcusego (1991) oraz Ericha Fromma (1995). Na opozycyjny wobec modusu „mieć” modus „być” złożyły się, według Fromma, samorealizacja, harmonijne współistnienie $z$ innymi, świadoma konsumpcja zgodna z rzeczywistymi potrzebami, nie zaś tymi narzucanymi przez modę lub grę statusową, autentyczne (nie prowadzące do alienacji) przeżycia. $Z$ kolei forma bycia, jaką jest „mieć”, uzależnia jednostkę od rzeczy, od tego, co posiada; „rzecz posiada mnie, gdyż moje poczucie tożsamości, mój normalny stan psy- 
chiczny, wspiera się na posiadaniu rzeczy" pisał Fromm (1995, s. 135). Istotna jest też wieloaspektowa krytyka rozwiniętych społeczeństw kapitalistycznych, nastawionych na produkcję dóbr materialnych i konsumpcję, wprowadzających alienację, zniewolenie, bierność, dominację orientacji rynkowej, fałszywe i zuniformizowane potrzeby (Marcuse 1991; Adorno, Horkheimer 1994). Kontestacja uwarunkowań społecznych nasila się wraz z postępem procesów nadmiernego stechnicyzowania, dominacji paradygmatu konsumpcyjnego, sformalizowania i urzeczowienia relacji między jednostkami.

\section{PRZEJAWY DOBROWOLNEJ PROSTOTY}

Dobrowolna prostota nie jest kategorią jednorodną, można bowiem wyodrębnić różne działania zmierzające do upraszczania życia. Określające ją linie podziałów przebiegają $\mathrm{w}$ różny sposób - w zależności od zakresu wprowadzanych zmian, ich natężenia, obszarów, w których się przejawia.

Elgin i Mitchell (1977, s. 28) określili Voluntary Simplicity Movement jako „Wszechogarniającą zmianę społeczną transformującą tradycyjny system wartości". Ich rozważania osadzone są w kontekście społeczeństwa amerykańskiego. Zestawiają oni dwa systemy aksjonormatywne. Jeden — istniejący — związany jest $z$ industrialną formą organizacji społecznej, drugi - wyłaniający się, projektowany - jest oparty na aksjologii dobrowolnej prostoty. Pierwszy typ ładu społecznego cechują: materialne nastawienie (w tym dążenie do wzrostu i kumulacji), koncepcja człowieka chcącego panować nad naturą, realizacja interesów naznaczona rywalizacją, „ostry” (rugged) indywidualizm, racjonalność. $Z$ kolei system społeczny ufundowany na wartościach prostego życia przesuwa akcenty i dokonuje korekt poprzedniego. Cechuje go: „wystarczający” poziom materialności połączony z psycho-duchowym rozwojem, wyobrażenie człowieka żyjącego w zgodzie z naturą, równoważenie interesów własnych i cudzych, „kooperacyjny” indywidualizm, racjonalność i intuicja. W miejsce masowo produkowanych, ujednoliconych produktów te, które są ręcznie wytwarzane, unikatowe, solidne i wytrzymałe. Mimo dostrzegalnego naznaczenia tego projektu cechami utopii bardziej akcentują oni — jako być może najważniejsze - poszukiwanie rozsądku i równowagi niż naiwną i niemożliwą realizację romantycznych wizji.

Przedstawione przez Elgina i Mitchella dwa typy społeczeństw mają charakter typów idealnych, ich deskrypcje są wyostrzone i spotęgowane (zgodnie $z$ wytycznymi Maksa Webera), opisują de facto pewien rodzaj empirycznej fikcji. Dychotomia ta pozwala jednak stworzyć obejmującą całą zbiorowość typologię postaw wobec dobrowolnej prostoty. Kluczowe jest nastawienie do dobrowolnej prostoty, co pozwala włączyć także osoby spoza kręgu jej admiratorów - można bowiem wyróżnić zaangażowanie, akceptację lub obojętność (rzadziej zapewne wrogość i niechęć, choć one również mogą się zdarzać). Autorzy wskazują na następujące postawy: całościowej lub częściowej afirmacji proste- 
go życia, sympatyzowania z tą ideą, obojętności wobec niej i nieświadomości jej istnienia lub jej negacji (Elgin, Mitchell 1977, s. 17-19).

„Całościowych" zwolenników voluntary simplicity cechuje, obok zinternalizowania odpowiednich przekonań, wielokierunkowa aktywność, na przykład domowa uprawa roślin ${ }^{3}$, recykling, preferowanie żywności naturalnej (dotyczy to zarówno jej nabywania, jak i przygotowywania posiłków), prosty ubiór, użytkowanie komunikacji publicznej, zorientowanie na rodzinę, praktykowanie medytacji lub innych form osobistego rozwoju. Zwolennicy „częściowi” stanowią zbiorowość liczebnie większą, stosują kilka wybranych zasad — mieszczą się więc w kategorii redukujących (downshifting). „Sympatycy” z kolei wyrażają zainteresowanie światopoglądem, ale jednocześnie zachowują dystans, nie „praktykują", a „niezainteresowani” są to zarówno nisko usytuowani w hierarchii społecznej, czyli oddaleni od sfery obfitości, jak i ci, którzy są zanurzeni w konsumpcyjnej logice systemu.

Amitai Etzioni (1998, s. 620-624) wyróżnił natomiast trzy warianty voluntary simplicity różniące się zakresem i intensywnością wprowadzanych zmian od powściągliwości, umiarkowania (moderate), przez znaczącą restrukturyzację życia (strong simplifiers), skończywszy na całościowej transformacji i przemianie wszystkich aspektów życia (Simple Living Movement). Kluczem podziału jest zasobność finansowa i status społeczny oraz rodzaj wykonywanej profesji w każdej z tych kategorii można znaleźć osoby reprezentujące różny stan majątkowy, co pokazuje klasowo i materialnie determinowane afiliacje.

Przyjrzyjmy się wyodrębnionym przez autora postawom, eksponując zwłaszcza pierwszą z nich - downshifting, ona bowiem w najwyższym stopniu odzwierciedla minimalistyczne formy „sprzeciwu” wobec konsumpcyjnych aktywności. Zwalnianie biegu w tym sensie oznacza redukcję konsumpcyjnej ostentacji (niekoniecznie wiążącą się ze spowolnieniem tempa życia, co jest $z$ definicji przypisane wszelkim odmianom slow), wyrażającą się między innymi w rezygnacji z posiadania i użytkowania luksusowych dóbr, jednak przy zapewnieniu bezpieczeństwa egzystencjalnego. Downshifting jest więc kontynuacją konsumpcyjnie zorientowanego stylu życia, który ma jednak — przynajmniej w założeniu - mniej wystawny charakter. Przy czym, zdaniem autora, należy wyraźnie odróżnić tych, którzy dobrowolnie ograniczają konsumpcję, na przykład przez kontrolowanie wysokości wydatków, chęć oszczędzania, od tych, którzy jedynie wymieniają pewną część dóbr na inne - dokonują „uproszczenia” w znaczeniu ograniczenia ilości posiadanych rzeczy ${ }^{4}$. Ich styl życia sta-

\footnotetext{
${ }^{3}$ Przykładem popularności działań o takim charakterze są ogródki działkowe traktowane jako minipola upraw. Innej ilustracji dostarczają spółdzielnie tworzone w celu kupowania i dystrybucji produktów pochodzących od lokalnych rolników (z pominięciem tradycyjnej sieci pośredników) oraz kooperatywy zawiązywane $z$ intencją wspólnego uprawiania warzyw, owoców w wielkomiejskich warunkach, na przykład na dachach biurowców.

${ }^{4}$ Szerzej pojmowany downshifting, poza ograniczeniem kompulsywnego materializmu, obejmuje również takie działania zmierzające do uproszczenia życia jak: wycofanie się z rywalizacji i współ-
} 
je się przez to „prostszy”, choć nadal kosztowny - kupuje się mniej rzeczy, ale o wyższej jakości, droższych. Typowa dla tej umiarkowanej formy wymiana przedmiotów nie wiąże się zatem ze zmianą ich funkcji w życiu jednostki (zob. Krajewski 2008) — ich rola najczęściej pozostaje taka sama, są symbolami konsumpcji.

Strong simplifiers (intensywnie upraszczający) to wysoko wykwalifikowani profesjonaliści, osiągający wysokie dochody, którzy z racji wykonywanych obowiązków są szczególnie narażeni na stres, wypalenie zawodowe, choroby psychosomatyczne. Porzucają oni dotychczasowy — nadmiernie eksploatujący sposób funkcjonowania, wybierając niższy dochód, ale zyskując więcej czasu wolnego i mniej stresujące życie. Dostrzegalne jest wprowadzenie zasady „mniej kupowania i zarabiania”, którą określa się jako „cichą rewoltę przeciwko dominującej kulturze posiadania i wydawania" (Etzioni 1989, s. 622).

Trzeci rodzaj praktyk wyróżniony przez Etzioniego - simple living movement to całościowa zmiana zmierzająca do uproszczenia życia. Obserwowana w tym przypadku najbardziej rozległa skala zmian — na przykład przeprowadzka w spokojniejsze, mniej zaludnione miejsce — jest motywowana filozoficznie, przez odniesienia do koncepcji Duane Elgina, poglądów i przekonań transcendentalistów amerykańskich (Ralpha Waldo Emersona, Henry'ego Davida Thoreau), etosu purytańskiego.

\section{GENEZA I ZAŁOŻENIA MINIMALIZMU}

Minimalizm może być postrzegany jako kontynuacja ruchu dobrowolnej prostoty; ,[m]inimalizm jako wybór stylu życia stanowi jedną $\mathrm{z}$ alternatyw dla masowej konsumpcji współczesnych społeczeństw i jako taki wpisuje się w długą historię indywidualnej oraz zbiorowej kontestacji pragnienia posiadania rzeczy oraz krytyki materialistycznej orientacji życiowej” (Kasperek 2013, s. 119). Porównanie ujawnia płynność granic między minimalizmem a ideą prostego życia; uzasadnia to — zdaniem niektórych - wymienne posługiwanie się tymi terminami. Dobrowolna prostota ma jednak znaczeniowo szerszy zakres, choć wiele jej cech odnajdziemy w konceptualizacjach minimalizmu — prostota materialna i rozwój osobowy to najważniejsze $z$ nich.

Termin „minimalizm” jest pojemny; nie ma jednej, podzielanej przez wszystkich definicji określającej jednoznacznie, co oznacza bycie minimalistą. Każdy tworzy własną wersję minimalizmu, podobnie jak tworzy się różne wersje slow life - jednostka wybiera z zestawu różnorodnych elementów, konstru-

zawodnictwa, dążenie do zredukowania stresu oraz nadmiernych kosztów psychologicznych związanych z pracą zawodową, w której zbyt duży nacisk kładzie się na wzrost efektywności, produktywności. Chodzi tu zatem, po pierwsze, o znalezienie, a po drugie - o udoskonalanie równowagi między pracą a czasem wolnym (work-life balance), większą koncentrację na rozwoju osobistym oraz budowaniu relacji interpersonalnych niż na sukcesie ekonomicznym. 
ując tym samym unikatową konfigurację przekonań i zachowań. W efekcie tych decyzji powstają autoidentyfikacje oparte nie tylko na stosunku do rzeczy, rozumieniu ich roli i znaczenia $\mathrm{w}$ życiu codziennym (w slow life odnosi się to do czasu poświęcanego na różne aktywności i działania), ale również na odwołaniu do różnych światopoglądów - najczęściej ekologii, wegetarianizmu, alterglobalizmu. $Z$ tej perspektywy interpretowane minimalizm i slow life są egzemplifikacjami praktyk komponowania nowych znaczeń $z$ dostępnych idei i artefaktów kulturowych. Te zrekonfigurowane znaczenia i sensy są wykorzystywane w procesie konstruowania tożsamości jednostkowej oraz związanego $z$ nią stylu życia.

Minimaliści kwestionują definiowanie jednostek poprzez gromadzone i użytkowane przez nie przedmioty traktowane jako podstawa sensu egzystencji. Aksjomatem jest dla nich rozłączenie kategorii szczęścia i posiadania w wymiarze materialnym. Przywołuje się w tym kontekście badania dowodzące, że wzrost zasobności finansowej i własności (od pewnego poziomu) nie powoduje zwiększania poczucia jednostkowego szczęścia i satysfakcji życiowej (zob. Frank 2008; Górnik-Durose 2002) ${ }^{5}$. Dystansują się oni również od przekonania, że dobra materialne są dominującym wyznacznikiem pozycji społecznej oraz środkiem służącym budowaniu prestiżu, szacunku i uznania społecznego (zob. Bauman 2009). Cechuje ich także krytyka powszechnych w społeczeństwie konsumpcyjnym postaw związanych z bezrefleksyjnym (często kompulsywnym i irracjonalnym) kupowaniem i wyrzucaniem, podtrzymujących intensywną rotację dóbr. Nie oznacza to, że minimalizm jest jednoznacznie antykonsumpcyjny (zob. Kasperek 2016), choć takie wyobrażenie dominuje $\mathrm{w}$ jego społecznej recepcji. Jest on raczej, jak wynika $z$ autoidentyfikacji minimalistów, przykładem świadomej konsumpcji (Kramarczyk 2015), formą indywidualnego protestu wobec nadmiaru identyfikowanego $z$ hiperkonsumpcją. Utożsamianie minimalizmu $z$ antykonsumpcją ma więc jedynie heurystyczny charakter. Właściwa dla niego deklarowana intencjonalna rezygnacja może być bowiem postrzegana jako specyficzna forma zachowań konsumpcyjnych, w których ostentację zastępują umiar i ograniczenia (zob. Baudrillard 2006), stając się podstawą różnicowania społecznego.

Minimalizm - w omawianym znaczeniu - upowszechnił się po 2008 ro$\mathrm{ku}$, co wiązało się z kryzysem systemu kapitalistycznego, recesją ekonomiczną i załamaniem zaufania do elit finansowych oraz politycznych. O ile wcze-

${ }^{5}$ Zależność między poziomem dochodów a poczuciem satysfakcji i zadowolenia nie jest oczywiście tak jednoznaczna. Na podstawie wyników wielu badań Małgorzata Górnik-Durose (2002, s. 121-122) formułuje wniosek, że ważne są różne czynniki: zasób środków finansowych znajdujących się w dyspozycji jednostki, dostęp do dóbr i swoboda ich nabywania, poczucie bezpieczeństwa finansowego (zgromadzone rzeczy materialne, a także umiejętności i kompetencje jednostki) oraz niezależność finansowa (umożliwiająca dokonywanie wyborów). Status materialny jest jedynie jednym z korelatów szczęścia; istotniejsze są między innymi relacje międzyludzkie, zagospodarowanie czasu wolnego, pozytywne doświadczenia. 
śniej terminem tym określano nurt w filozofii, sztuce, językoznawstwie, o tyle w ostatniej dekadzie zaczął być identyfikowany ze stylem życia alternatywnym — mniej lub bardziej - wobec postaw zorientowanych konsumpcjonistycznie i materialistycznie.

\section{MINIMALIZM — OD IDEI DO PROJEKTU}

Minimalizm ewoluuje, zachodzą $\mathrm{w}$ tym nurcie procesy wewnętrznych przeobrażeń i różnicowania. Są one wynikiem przeobrażania się uwarunkowań społeczno-kulturowych, ekonomicznych i politycznych, a także zmian środowiska medialnego. Pierwsze artykulacje przekonań minimalistów pojawiły się w formie blogów (część z nich istnieje do dzisiaj), a obecnie w znacznej mierze są one rozpowszechniane $\mathrm{w}$ formie książek poradniczych. W początkowej fazie minimalizm miał wyraźnie kontestacyjny charakter - sprzyjał temu internet jako medium kultur alternatywnych. Wśród jego użytkowników dostrzegalny był opór wobec powszechnych praktyk konsumpcyjnych, krytyka mechanizmów gospodarki kapitalistycznej oraz dyskusje nad możliwościami ich przeobrażeń (głównie z perspektywy zmiany indywidualnych zachowań). Obecnie jest coraz bardziej „zawłaszczany” przez przemysł, reklamę i marketing, które przedstawiają minimalizm jako spójny i kompleksowy projekt tożsamościowy przejawiający się w określonym stylu życia. Ilustruje to zarazem przejście od niszowego, subwersywnego znaczenia praktyk minimalistycznych do wkomponowania ich w logikę rynku, wcześniej przez minimalistów kontestowaną.

$\mathrm{W}$ publikacjach ${ }^{6}$, które $\mathrm{W}$ większości powstały na bazie wcześniej istniejących blogów, minimalizm jest utożsamiany z zaleceniem posiadania mniej $\mathrm{w}$ sensie materialnym, co pozwoli osiągnąć więcej w niematerialnych sferach życia. Fumio Sasaki (2017, s. 18) definiuje minimalizm ,jako (1) ograniczenie się do posiadania wyłącznie niezbędnych rzeczy oraz (2) pozbycie się nadmiaru przedmiotów, żeby skupić się na tych, które faktycznie są dla nas ważne". Pierwszym etapem procesu stawania się minimalistą jest rozpoznanie, co w życiu jednostki jest zbędne, co należy ograniczyć lub wyeliminować. Kolejnym etapem jest określenie tego, co jest znaczące i ważne - dla każdego będą to inne wartości i dążenia, mające jednak wspólny niematerialny rdzeń. Minimalizm — pisze jedna z autorek (Konopek 2017, s. 55) — „jest świadomością własnych celów i potrzeb". W takim ujęciu jest to narzędzie, które pozwala na „celowe oddawanie się temu, co dla nas najważniejsze, i usuwanie wszystkiego, co nam w tym przeszkadza" (Becker 2017, s. 28). Jak podkreślają minimaliści: „nie jest [on] i nigdy nie powinien stać się celem samym w sobie, ale jedynie narzędziem w drodze do celu. [...] Jeśli chcemy wieść proste, mądre i harmo-

6 Publikacje poświęcone minimalizmowi wydane w ostatnich latach w Polsce oraz wykorzystane w analizie to: Mularczyk-Meyer 2014, 2015; Kędzierska 2016; Jay 2016; Becker 2017; Sasaki 2017; Konopek 2017. 
nijne życie, musimy zrozumieć, które wartości są dla nas ważne, bowiem to one prowadzą nas przez życie i z nich wypływa wszystko inne" (Kędzierska 2016, s. 21, 22). Anna Mularczyk-Meyer (2014, s. 10) wyróżnia obszary, w których przejawia się minimalizm, a także wskazuje na stosowane w nim strategie: „Minimalizm polega na odejmowaniu i ciągłym zdawaniu sobie pytań. [...] To wielkie porządki i poszukiwania prostoty - na początku w przestrzeni materialnej, także $\mathrm{w}$ sferze ciała, potem $\mathrm{w}$ umyśle, wreszcie $\mathrm{w}$ relacjach $\mathrm{z}$ innymi ludźmi”. Bez spełnienia „wstępnych” warunków zredukowania (i spowolnienia w slow life) nie jest możliwe przejście do kolejnych etapów procesu upraszczania życia. Rolę przedmiotów w poglądach minimalistów w slow life zastępuje podejście do czasu i chęć sprawowania nad nim kontroli (minimaliści próbują ją sprawować nad przedmiotami). Wynika to z przekonania, że dotychczasowa egzystencja - zbyt pospieszna, angażująca w wielość wyzwań, przez co rozpraszająca - nie spełnia kryteriów satysfakcjonującego życia. Rozpoznanie tego, co istotne, nie musi być niezmienne i kompleksowo określać jednostkę. Kluczowe jest wyznaczenie priorytetów w danym momencie najważniejszych i koncentracja na ich realizacji (np. życie rodzinne, rozwój duchowy, praca jako pasja).

Tym samym minimalizm jest przejawem kultury indywidualizmu, w której jednostka projektuje swoje życie z zastosowaniem instrumentów oferowanych przez system społeczno-ekonomiczny. Jako taki instrument minimalizm oferuje diagnozy i wzory działań do wykorzystania przez jednostki, które poszukują różnych metod samorealizacji. Z jednej strony odwołuje się do (autentycznych) potrzeb wielu jednostek, sygnowanych przez dobrowolną prostotę (np. poszukiwanie ludzkiej miary, modus „być” zamiast „mieć”), z drugiej jako motyw skonstruowany na tych właściwościach jest przetwarzany przez marketing, reklamę i kulturę popularną. W ten sposób chęć wyzwolenia się spod presji konsumpcji przyczynia się, paradoksalnie, do specjalizacji oferty rynkowej ukierunkowanej na zaspokajanie antykonsumpcyjnych potrzeb. Jak zauważają Joseph Heath i Andrew Potter (2010, s. 126, 191-192): „rynek niewątpliwie świetnie reaguje na zapotrzebowanie konsumentów na antykonsumpcyjne produkty oraz literaturę. [...] Większość działań określanych powszechnie jako «antykonsumpcyjne» na nic się zdaje. Często odnoszą wręcz przeciwny skutek, sprzyjając rywalizacyjnej konsumpcji". Minimalizm w zmediatyzowanej, niejednokrotnie zbanalizowanej i zmerkantylizowanej formie staje się kolejną modą $^{7}$ — „kulturowym trendem kształtującym styl konsumpcji” (Krajewski 1997,

7 „Obecnie panuje niezdrowa moda na minimalizm. Wszystko, co jest simple i minimalist, sprzedaje się jak świeże bułeczki. Jest to oczywiście sprytnie wykorzystywane przez reklamowych speców. Kampanie planowane są w ten sposób, by wydawało się, że kupując rzeczy uznane za minimalistyczne, postępujemy słusznie. W końcu wyłamujemy się ze schematu konsumpcjonizmu i wybieramy to, co jest klasyczne i powściągliwe, a nie po prostu modne. Poza tym pozbywamy się balastu, który już posiadamy, a to przecież same plusy" (Konopek 2017, s. 54). Dostrzegane jest to przez samych minimalistów. 
s. 15) - przejawiającą się w sposobach organizacji przestrzeni, spędzania czasu wolnego, wyposażeniu wnętrz, wzornictwie, odżywianiu itd. Powszechnie dostępne poradniki oraz instruktaże przedstawiające syntetycznie opracowane reguły życiowych konwersji poddają jednostkę większej samokontroli (Jacyno 2007; por. Beck 2001), konformizują ją, czyniąc autonomię indywidualnych wyborów jedynie pozorem (Giddens 2001; Marody 2015).

Minimalizm pojmowany jako „projekt Ja” wpisuje się w założenia kultury terapeutycznej, w której praktyki społeczne mają charakter rynkowy. W zaleceniach minimalistów dobrze widoczny jest schemat „biograficznej przemiany” dokonywanej według właściwego dla niej wzorca: „najpierw trzeba określić pragnienia i potrzeby. [...] Potrzeby i pragnienia dzieli się na "wyższe» i «niższe», «zdrowe» i "chore», wskazuje się priorytety, rzeczy, z których można albo trzeba zrezygnować, potem przychodzi czas na ustalenie strategii, kolejnych kroków niezbędnych do osiągnięcia tego, co wskazane zostało jako priorytety" (Jacyno 2007, s. 175). Za nadrzędne potrzeby (wartości) minimaliści uznają zarówno „pragmatyzm”, „wygodę”, „oszczędność”, „estetykę”, „ład”, „piękno” (jako wymiary egzystencji minimalistycznej), jak i „szczęście”, „spełnienie”, „wolność”, „niezależność” (jako postawy, które powinny określać jednostkę będącą/stającą się minimalistą). Szczególne miejsce zajmuje w tej hierarchii „wdzięczność” rozumiana jako zadowolenie $z$ tego, co się posiada, jak i docenianie różnych zdarzeń, dziękowanie innym za ich obecność (Kędzierska 2016, s. 109-110; Becker 2017, s. 187-188). „Funkcjonalność, „niezbędność” i „praktyczność” to z kolei atrybuty rzeczy, które jednostka pozostawia sobie i użytkuje. Kontrola sprawowana nad rzeczami - mniej lub bardziej iluzoryczna - ma korespondować $z$ potencjalnymi zmianami poznawczymi i behawioralnymi $\mathrm{w}$ różnych aspektach życia jednostki. Minimalizm jako narzędzie umożliwia zatem realizację wielu, nakładających się, celów; początkowo związanych z oczyszczeniem przestrzeni z nadmiaru przedmiotów, w późniejszym czasie $z$ "panowaniem” nad rzeczami oraz wypełnianiem życia dążeniami odmiennymi od materialnych. Pojawiające się w tym kontekście kategorie, takie jak „poczucie komfortu”, „wysoka jakość życia”, „pełnia życia”, są więc konsekwencją wykonania planu złożonego z powiązanych elementów - tego, co ma być wyeliminowane i tego, co ma być rozwijane.

Osobiste i społeczne znaczenie poczynań jednostki jest wyznaczane - według minimalistów — przez wzrost jakości codziennego życia, subiektywny dobrostan, pielęgnowanie relacji rodzinnych, intymnych i społecznych, uważność (mindfulness), rozwój intelektualny oraz duchowy ${ }^{8}$, nie zaś wysoki poziom dochodu i konsumpcji. Bezpieczeństwo materialne jest oczywiście niezbędne, by móc ukierunkować swoją aktywność na cele niematerialne, przysparzające takich niewymiernych „dóbr” jak doświadczenia, doznania, wrażenia związane

${ }^{8}$ Na temat duchowego wymiaru minimalizmu zob. Kasperek 2013, 2014a, 2014b, 2015, 2016. 
z podróżami, twórczością, kontemplacją ${ }^{9}$. $Z$ tego powodu minimalizm jest postrzegany głównie jako styl życia klasy wyższej i średniej, która dysponuje środkami finansowymi na jego urzeczywistnianie. Wartości postmaterialistyczne, zbieżne $z$ ideą samorealizacji i jej przejawami: autonomią, indywidualizmem, autoekspresją (Inglehart, Welzel 2007), nie są jednak charakterystyczne wyłączne dla tego stylu życia. Zgodnie $z$ diagnozami Ronalda Ingleharta (1990, 1997) obrazują one przekierowanie aksjologiczne dostrzegalne w społeczeństwach rozwiniętych, w których zapewnione jest zaspokojenie potrzeb materialnych. Wskazuje to na jeden $z$ wielu paradoksów minimalizmu; jak zauważa Andrzej Kasperek (2014b, s. 6-7): „[w] minimalizm, jako formę światopoglą$\mathrm{du}$, wpisana wydaje się zasadnicza antynomia: $z$ jednej strony chodzi o eksponowanie kontrkulturowego par excellence dążenia do zakwestionowania kulturowego imperatywu konsumowania i gromadzenia, z drugiej strony, rzecznicy prostoty podzielają wartości budujące mainstream kulturowy współczesnych zaawansowanych cywilizacyjnie społeczeństw (zorientowanych postmaterialistycznie)". Widoczne jest tu również napięcie między gospodarką opartą na wzorach konsumpcji a rynkiem idei zdominowanym przez myślenie kontrkulturowe (zob. Heath, Potter 2010).

\section{PRZEJAWY MINIMALIZMU}

Minimalizm jako narzędzie wykorzystywane w realizacji projektu Ja cechują odmienności w intensywności i skali dokonywanych zmian. Można tu wyodrębnić kilka wariantów; zabieg ten ma głównie charakter analityczny, mogą one bowiem koegzystować.

Radykalna wersja minimalizmu niekiedy jest kojarzona z karykaturalnymi propozycjami ograniczania posiadanych przedmiotów do ich jak najmniejszej liczby (tylu, ile zmieści się w walizce, plecaku). „Fin Henri Juntilla i Amerykanin Leo Babauta przez jakiś czas radzili sobie, posiadając 43 przedmioty. Nina Yau do szczęścia potrzebowała 47 rzeczy. Colin Wright nie mógł się obejść jedynie bez 51 przedmiotów. Wszystko zaczęło się od blogera Dave'a Bruno, który rzucił swoim czytelnikom wyzwanie 100 przedmiotów" (Wallman 2017, s. 114). Jest to swoiste współzawodnictwo w zakresie tego, do jakiego stopnia można zredukować stan posiadania (nasuwa się analogia do potlaczu - przez skrajną redukcję dóbr jednostka buduje swój status). Wydaje się, że — paradoksalnie - uwaga jest skoncentrowana na aspekcie materialnym, nieustannym myśleniu o przedmiotach, o tym, czego jeszcze można się pozbyć, jaki bardziej wielofunkcyjny przedmiot będzie lepiej spełniał rolę zaspokajania większej ilości potrzeb itd. Zastosowanie miałoby tu przekonanie Marka Krajewskiego, że de facto minimaliści znajdują się „we władaniu” rzeczy, od których chcą się

\footnotetext{
${ }^{9}$ Niekiedy wskazuje się na niebezpieczeństwo zastępowania gromadzenia przedmiotów kolekcjonowaniem przeżyć (Wallman 2017).
} 
uwolnić. Ten typ minimalizmu jest atrakcyjny medialnie, symbolizują go puste, białe pomieszczenia $z$ wyeksponowanymi pojedynczymi meblami i nielicznymi ozdobami - obraz dość rozpowszechniony, zwłaszcza w kulturze popularnej.

Minimalizm może mieć też charakter „ekskluzywny”. Choć w wypowiedziach minimalistów pojawiają się deklaracje, że nie chodzi o zamianę seryjnych, tanich produktów na artykuły o wyższej jakości, krytycy dostrzegają jednak pewien rodzaj elitarnej ostentacji przejawiającej się w preferowaniu rzeczy kosztownych, markowych i unikatowych. Ten rodzaj minimalizmu byłby przykładem „praktyk wysokiego statusu warunkowanych klasowo” (Duda 2013, s. 50). Odwołania do jakości są zresztą artykułowane expressis verbis $\mathrm{w}$ przekazach minimalistów: „Im mniej pieniędzy wydajecie na nadmierną liczbę przedmiotów, tym większą macie sposobność zakupu przedmiotów wysokiej jakości, gdy ich potrzebujecie. Minimalizm to niekoniecznie to samo, co oszczędność. To filozofia uznająca, że nie «im więcej rzeczy, tym lepiej», tylko raczej: «im lepsze rzeczy, tym lepiej»" (Becker 2017, s. 19). Wysoka jakość nabywanych przedmiotów i urządzeń pozwala użytkować je dłużej, wiąże się z ich większą trwałością (wynikającą z wykonania, zastosowanych materiałów) oraz często wielofunkcyjnością. Akcentowanie tych właściwości pozwala ograniczyć kupowanie nowych przedmiotów, jest też formą niezgody na masowo produkowane, mizernej jakości towary. Prymat jakości nad ilością przejawia się także w ograniczeniu liczby godzin przeznaczanych na nieproduktywne i pozbawione znaczenia aktywności i wybór tych, które mają dla jednostki wyższą symboliczną wartość (jest to cecha, która łączy minimalizm ze slow life).

Z kolei minimalizm postrzegany nie jako „dystynkcja w nadmiarze, ale strategia na czas kryzysu” (Skowrońska 2013, s. 90) to opcja bardziej „ekonomiczna". Polega na różnorodnych działaniach związanych z przetwarzaniem rzeczy, nadawaniem im „drugiego życia” poprzez niekupowanie nowych ich wersji, poddawanie naprawom, użyczanie innym, współużytkowanie. Istotne jest tu również opracowywanie strategii konsumenckich pozwalających ograniczać zbędne wydatki oraz oszczędzać pieniądze, na przykład przez planowanie zakupów, nieuleganie konsumpcyjnym zachciankom i impulsom. Służy temu również samodzielne wytwarzanie dóbr poza systemem płatnych usług (np. uprawa warzyw we własnych ogródkach, przygotowywanie przetworów, szycie odzieży, robienie na drutach). Uzasadnieniem dla tych aktywności — zgodnie ze schematem prosumpcji (zob. Toffler 1997; Mika 2014) — nie jest jedynie ograniczoność zasobów finansowych (a więc rodzaj konieczności), mogą one być również dystynktywnym, intencjonalnie wybieranym elementem stylu życia ${ }^{10}$. Jak pisze Francine Jay (2016, s. 66): „Należy jak najbardziej ograniczyć konsumpcję oraz wybierać produkty i opakowania $z$ biodegradowalnych mate-

10 Podobnie jak kupowanie rzeczy lokalnych i sezonowych, zwracanie uwagi na skład oferowanych produktów, miejsce ich pochodzenia oraz wykonanie - jako cechy bardziej świadomej i poddanej refleksji konsumpcji, a jednocześnie forma odróżniania się od innych. 
riałów i recyklingu. Kupowanie lokalnych produktów jest etyczne, ekologiczne, przynosi korzyści ekonomiczne. Ograniczanie zakupów do tych niezbędnych jest najlepszym sposobem na zmniejszenie negatywnych skutków konsumpcji". Wymienione praktyki są przykładem dekonsumpcji, której istotę stanowi racjonalizacja konsumpcji, dostosowanie jej do faktycznych potrzeb jednostki (zob. Bywalec, Rudnicki 2002).

Niejednorodność minimalizmu jest przyczyną trudności z zaklasyfikowaniem go do jednolitej kategorii działań społecznych. $Z$ jednej strony jego cechą charakterystyczną jest krytyczny stosunek do hiperkonsumpcji połączony z postulatami jej zracjonalizowania — zastąpienia jej świadomą konsumpcją. $Z$ drugiej strony ograniczenie konsumpcji dotyczy głównie dóbr materialnych, nie obejmuje tych o charakterze niematerialnym (przeżyć, doświadczeń i doznań); właśnie one są proponowane jako cele minimalistycznych dążeń. Ten postmaterialistyczny zwrot pozwala ujmować minimalizm jako formę dystynkcji manifestowaną przede wszystkim przez jednostki należące do klasy wyższej i średniej, które mają zaspokojone potrzeby materialne. Trudno zatem jednoznacznie rozstrzygnąć, czy minimalizm jest przykładem oporu i subwersji, czy nową formą różnicowania społecznego (wydaje się, że między tymi kategoriami nie musi występować zasadnicza sprzeczność), czy wręcz wyrazem konformizmu (przystosowania do panującej mody). Proponowany przez minimalizm rodzaj „kontestacji” jest bowiem skomercjalizowany, podobnie jak pozostałe formy buntu i sprzeciwu wobec dominujących praktyk społecznych.

Jednocześnie należy odróżniać minimalizm pojmowany jako zinternalizowany system przekonań cechujący minimalistycznych „purystów” od chwilowej mody „obsługiwanej” przez jego marketingową wersję (zob. Skowrońska 2013), gdyż krytycznie zorientowani wobec konsumpcyjnych wzorów dystansują się wobec upowszechnianych medialnie przekazów.

Przekonania i zachowania składające się na minimalizm i slow life, choć wyrastają $z$ ugruntowanego $\mathrm{w}$ kulturze zachodniej poszukiwania tego, co proste (zgodne $z$ naturą, przesiąknięte duchowością), luźno odwołują się do wartości dobrowolnej prostoty. Zapożyczone $z$ tej idei treści funkcjonują w odmiennym kontekście społeczno-kulturowym, wyznaczanym przez ramy kultury poradniczej, terapeutycznej, kultury indywidualizmu, logikę kapitalizmu i mechanizmy rynkowe.

\section{BIBLIOGRAFIA}

Alexander Samuel, 2011, The Voluntary Simplicity Movement: Reimagining the Good Life beyond Consumer Culture, „The International Journal of Environmental, Cultural, Economic and Social Sustainability", nr 7, s. 4-21. 
Baudrillard Jean, 2006, Społeczeństwo konsumpcyjne: jego mity i struktury, tłum. Sławomir Królak, Wydawnictwo Sic!, Warszawa.

Bauman Zygmunt, 2009, Konsumowanie życia, Wydawnictwo Uniwersytetu Jagiellońskiego, Kraków.

Becker Joshua, 2017, Im mniej, tym więcej. Dzięki minimalizmowi masz wszystko, czego potrzebujesz, Znak, Kraków.

Bywalec Czesław, Rudnicki Leszek, 2002, Konsumpcja, Polskie Wydawnictwo Ekonomiczne, Warszawa.

Dopierała Renata, 2015, Między konwersacją a konsultacją. O zapośredniczonych komputerowo praktykach zmiany Ja, „Miscellanea Anthropologica et Sociologica”, nr 2.

Duda Aneta, 2013, Strategie oporu konsumenckiego - dezercja z rynku czy wspótpraca, „Kultura i Społeczeństwo", nr 4.

Elgin Duane, 2010 [1981], Voluntary Simplicity: Toward a Way of Life That Is Outwardly Simple, Inwardly Rich, Harper, New York.

Elgin Duane, Arnold Mitchell, 1977, Voluntary Simplicity, „The Co-Evolution Qarterly” (Summer), s. 4-19.

Etzioni Amitai, 1998, Voluntary Simplicity: Characterization, Select, Psychological Implications and Social Consequences, „Journal of Economic Psychology”, nr 19, s. 619-643.

Frank Robert H., 2008, Jak nie kupować szczęścia, w: Piotr Sztompka, Małgorzata Bogunia-Borowska (red.), Socjologia codzienności, Znak, Kraków, s. 318-333.

Fromm Erich, 1995, Mieć czy być?, tłum. Jan Karłowski, Rebis, Poznań.

Giddens Anthony, 2001, Nowoczesność i tożsamość. Ja i społeczeństwo w późnej nowoczesności, tłum. Alina Sulżycka, PWN, Warszawa.

Gregg Richard, 1977 [1936], The Value of Voluntary Simplicity, „The Co-Evolution Quarterly” (Summer).

Górnik-Durose Małgorzata, 2002, Psychologiczne aspekty posiadania - między instrumentalnościa a spoteczna użytecznościa dóbr materialnych, Wydawnictwo Uniwersytetu Śląskiego, Katowice.

Heath Joseph, Potter Andrew, 2010, Bunt na sprzedaż. Dlaczego kultury nie da się zagłuszyć, tłum. Hanna Jankowska, Muza, Warszawa.

Horkheimer Max, Adorno Theodor, 1994, Dialektyka Oświecenia, tłum. Małgorzata Łukasiewicz, Wydawnictwo IFiS PAN, Warszawa.

Inglehart Ronald, 1990, Culture Shift in Advanced Industrial Societies, Princeton University Press, New York.

Inglehart Ronald, 1997, Modernization and Postmodernization: Cultural, Economic and Political Change in 43 Societies, Princeton University Press, New York.

Inglehart Roland, Welzel Christian, 2007, Modernization, Cultural Change, and Democracy: The Human Development Sequence, Cambridge University Press, Cambridge.

Jacyno Małgorzata, 2007, Kultura indywidualizmu, Wydawnictwo Naukowe PWN, Warszawa.

Jay Francine, 2016, Minimalizm daje radość, tłum. Katarzyna Lipnicka-Kołtuniak, Muza, Warszawa.

Kasperek Andrzej, 2013, Antykonsumpcjonistyczna duchowość w czasach kryzysu, czyli Leo Babauty pochwata minimalizmu, „Przegląd Religioznawczy”, nr 2.

Kasperek Andrzej, 2014a, Minimalistów poszukiwania wewnętrznego spokoju, „Fragile”, nr 3-4.

Kasperek Andrzej, 2014b, Wyrażanie sprzeciwu poprzez duchowośc. Przypadek minimalizmu, „Stan Rzeczy", nr 2.

Kasperek Andrzej, 2015, Dobrowolna prostota jako przykład implicite religion, „Uniwersyteckie Czasopismo Akademickie" nr 4.

Kasperek Andrzej, 2016, Minimalistyczna duchowość jako przykład antykonsumpcjonistycznej duchowości. Perspektywa socjologiczna, „Zeszyty Naukowe KUL”, nr 4.

Kędzierska Katarzyna, 2016, Chcieć mniej. Minimalizm w praktyce, Znak Litera Nova, Kraków.

Konopek Natalia, 2017, Miej umiar. 52 kroki do życia po swojemu, Wydawnictwo Pascal, Bielsko-Biała. 
Krajewski Marek, 1997, Konsumpcja i współczesność. O pewnej perspektywie rozumienia świata społecznego, „Kultura i Społeczeństwo”, nr 3.

Krajewski Marek, 2004, Kultury alternatywne i konsumpcja, „Kultura Współczesna”, nr 3.

Krajewski Marek, 2008, Ludzie i przedmioty — relacje i motywy przewodnie, w: J. Kowalewski, W. Piasek, M. Śliwa (red.), Rzeczy i ludzie. Humanistyka wobec materialności, Instytut Filozofii Uniwersytetu Warmińsko-Mazurskiego, Olsztyn.

Kramarczyk Justyna, 2015, Mieć czy być? Minimalizm jako przykład świadomej konsumpcji w świetle badań własnych, „Prace Naukowe Uniwersytetu Ekonomicznego we Wrocławiu”, nr 414, s. 270-285.

Marcuse Herbert, 1991, Człowiek jednowymiarowy. Badania nad ideologia rozwiniętego społeczeństwa przemystowego, tłum. zbiorowe, Państwowe Wydawnictwo Naukowe, Warszawa.

Marody Mirosława, 2015, Jednostka po nowoczesności. Perspektywa socjologiczna, Scholar, Warszawa.

Mika Bartosz, 2014, Prosumpcja — niedoszła rewolucja, w: Piotr Siuda, Tomasz Żaglewski (red.), Prosumpcja: pomiędzy podejściem apokaliptycznym a emancypujacym, Wydawnictwo Naukowe Katedra, Gdańsk.

Mularczyk-Meyer Anna, 2014, Minimalizm po polsku, czyli jak uczynić życie prostszym, Black Publishing, Wołowiec.

Mularczyk-Meyer Anna, 2015, Minimalizm dla zaawansowanych, Black Publishing, Wołowiec.

Ritzer George, 2001, Magiczny świat konsumpcji, tłum. Ludwik Stawowy, Muza, Warszawa.

Sasaki Fumio, 2017, Pożegnanie z nadmiarem. Minimalizm japoński, tłum. Grzegorz Kulesza, Wydawnictwo Burda NG, Polska.

Skowrońska Marta, 2013, Minimalizm i chomikowanie: jak radzić sobie z nadmiarem przedmiotów?, „Kultura Współczesna”, nr 1.

Shi David, 1985, The Simple Life: Plain Living and High Thinking in American Culture, Oxford University Press, Oxford-New York.

Toffler Alvin, 1997, Trzecia fala, tłum. Ewa Woydyłło, PIW, Warszawa.

Wallman James, 2017, Rzeczozmęczenie. Jak żyć petniej, posiadając mniej, tłum. Katarzyna Dudzik, Insignis Media, Kraków.

Weber Max, Gospodarka i społeczeństwo. Zarys socjologii rozumiejacej, tłum. Dorota Lachowska, Wydawnictwo Naukowe PWN, Warszawa.

\title{
MINIMALISM-BETWEEN AN EPISODE AND DURATION
}

\author{
Renata Dopierała \\ (University of Łódź)
}

\section{Summary}

This article discusses minimalism and slow life as examples of anti-consumer-oriented social practices. The author presents the assumptions of minimalism and slow life (their similarities and differences), compares minimalism with the idea of voluntary simplicity (comparing mainly their systems of values), describes minimalism as a project of the self, and distinguishes a few variants-radical, economic, and luxury minimalism. The analysis is based on minimalist literature.

\section{Key words / słowa kluczowe}

minimalism / minimalizm, voluntary simplicity /dobrowolna prostota, post-materialist values / wartości postmaterialne, social movements / ruchy społeczne 